\title{
STUDI KELAYAKAN RENCANA JALUR EVAKUASI DAN LOGISTIK BENCANA POROS KERINCI - BUNGO, PROVINSI JAMBI
}

\author{
Aditya Pandu Wicaksono ${ }^{1,2}$, Riswanda Daniswara ${ }^{2}$, Didik Raharyono ${ }^{3}$ \\ ${ }^{1}$ Program Studi Teknik Lingkungan, Fakultas Teknologi Mineral, UPN "Veteran" Yogyakarta \\ Jl. SWK 104 Condong Catur, Depok, Sleman, Yogyakarta \\ 2 Pusat Studi Manajemen Bencana UPN "Veteran" Yogyakarta \\ ${ }^{3}$ Perkumpulan Peduli Karnivor Jawa
}

\begin{abstract}
Intisari - Provinsi Jambi merupakan kawasan rawan bencana gunungapi, gempabumi, banjir, dan tsunami. Keanekaragaman potensi bencana ini menuntut pengelolaan bencana yang memadai bagi kabupaten-kabupaten di wilayahnya. Kabupaten Kerinci merupakan kawasan yang rawan gempabumi dan gunungapi. Posisinya yang jauh dari Jalur Lintas Sumatra menjadikan jalur evakuasi dan logistik bencana merupakan hal penting. Kabupaten Bungo sebagai wilayah terdekat dan strategis sebagai pusat logistik. Penempatan pusat logistik ini perlu disertai jalur evakuasi koridor Kabupaten Kerinci-Kabupaten Bungo. Adanya perencanaan ini diharapkan mampu mengurangi risiko terjadinya korban ketika terjadi bencana. Kajian terhadap rencana jalur evakuasi dan logistik ini penting untuk dilakukan karena melewati Kawasan Taman Nasional Kerinci. Sesuai dengan Peraturan Menteri Kehutanan Nomor: P.56 /Menhut II/ 2006 Tentang Pedoman Zonasi Taman Nasional, diharapkan jalur evakuasi dan logistik ini dapat sebagai zona pemanfaatan dalam taman nasional yang tidak merusak kondisi alami daerah tersebut.

Penelitian ini menggunakan metode purposive sampling dalam penentuan rencana jalur evakuasi sedangkan penentuan kelayakan jalur evakuasi dan logistic menggunakan metode SWOT. Dari hasil kajian didapatkan bahwa (1) Kabupaten Bungo merupakan wilayah yang sesuai untuk dijadikan sebagai tempat pengembangan alternatif pusat logistik dengan mempertimbangakan posisi dan kondisi baik karakter bencana yang ada dan kondisi lingkungan eksisting yang ada. (2) Berdasarkan kajian yang dilakukan maka jalur evakuasi yang paling sesuai terletak di Kecamatan Limbur Lubuk Mengkuang di Kabupaten Bungo dan terhubung ke Kecamatan Siluak Mukai di Kabupaten Kerinci, Provinsi Jambi. (3) Pembukaan lahan untuk jalur evakuasi tidak menyebabkan keanekaragaman hayati yang ada menjadi berkurang karena di dalam jalur evakuasi tidak ditemukan flora fauna yang langka yang dilindungi. (4) Kebijakan pengembangan alternatif pusat logistik memiliki pengaruh yang besar dalam meningkatkan pembangunan daerah yang terdapat di Kabupaten Bungo walaupun memerlukan inventasi yang besar dalam pelaksanaannya.
\end{abstract}

Kata Kunci: kelayakan, Jalur evakuasi, logistik

\section{PENDAHULUAN}

Indonesia merupakan negara kepulauan yang secara geografis memiliki potensi yang tinggi terhadap kejadian bencana. Kejadian bencana dapat menyebabkan korban meninggal, korban luka berat dan luka ringan, pengungsian dan masalah sanitasi lingkungan. Adanya wilayah yang berupa kepulauan menyebabkan proses penanganan bencana harus dilakukan pada setiap daerah secara terencana. Peningkatan upaya kesiapsiagaan kabupaten rawan bencana dapat dilakukan dengan pemetaan sumber daya manusia, fasilitas kesehatan, sarana prasarana, logistik serta upaya penanggulangan krisis kesehatan. Adanya peningkatan kesiapsiagaan dan persebaran pusat logistik pada setiap daerah yang mempunyai kerentanan bencana tinggi memerlukan peran dari pemerintah daerah.

Provinsi Jambi mempunyai beberapa ancaman bencana diantaranya gunungapi, gempabumi, banjir, dan tsunami. Potensi bencana yang cukup beragam ini mengakibatkan perlunya pengelolaan bencana yang dalam hal ini pembuatan rencana jalur evakuasi dan penempatan pusat logistik. Daerah yang paling rawan terjadi bencana di Provinsi Jambi adalah Kabupaten Kerinci yang 
memiliki potensi bencana gempabumi dan gunungapi. Akan tetapi, belum ada rencana penanggulangan bencana yang ada. Kabupaten Bungo merupakan Kabupaten terdekat dari Kabupaten Kerinci yang merupakan wilayah strategis untuk ditempatkannya pusat logistik. Adanya penempatan pusat logistik ini perlu disertai jalur evakuasi koridor Kabupaten Kerinci-Kabupaten Bungo. Adanya perencanaan ini diharapkan mampu mengurangi risiko terjadinya korban ketika terjadi bencana.

Perencanaan jalur evakuasi sudah tercantum dalam peta Rencana Tata Ruang Wilayah (RTRW) Provinsi Jambi tahun 2011-2030. Dalam dokumen tersebut terdapat beberapa daerah yang terdapat koridor jalur evakuasi yakni Kabupaten Kerinci, Merangin, dan Kabupaten Bungo. Dalam hal ini poros Kerinci-Bungo yang terdapat di Kabupaten Bungo merupakan daerah yang memiliki potensi jalur evakuasi dan sebagai alternatif pengembangan pusat logistik. Hal ini disebabkan letak yang sangat strategis baik secara regional maupun nasional juga mempunyai relatif aman dari bencana jika dibandingkan daerah yang lain. Selain itu juga akses jalur evakuasi akan menghubungkan jalur jalan provinsi yang akan dilakukan suatu pelebaran jalan yang akan menuju ke bandara atau bahkan pelabuhan yang akan dibangun sebagai akses pendistribusian logistik apabila terjadi bencana gempabumi dan gunungapi. Jalur ini jelas akan mempercepat proses evakuasi dan penyaluran bantuan kepada masyarakat yang tinggal di Kabupaten Kerinci dan sekitarnya termasuk provinsi Bengkulu.

Rencana jalur evakuasi bencana melewati Kawasan Taman Nasional Kerinci. Berdasarkan Peraturan Menteri Kehutanan Nomor: P.56 /Menhut II/ 2006 Tentang Pedoman Zonasi Taman Nasional didalamnya juga telah diatur bahwa perlu ada zonasi khusus dan zona pemanfaatan dalam taman nasional. Zona khusus merupakan bagian dari taman nasional karena kondisi yang tidak dapat dihindarkan telah terdapat kelompok masyarakat dan sarana penunjang kehidupannya yang tinggal sebelum wilayah tersebut ditetapkan sebagai taman nasional antara lain sarana telekomunikasi, fasilitas transportasi dan listrik. Sedangkan Zona pemanfaatan merupakan bagian taman nasional yang letak, kondisi dan potensi alamnya, yang terutama dimanfaatkan untuk kepentingan pariwisata alam dan kondisi/jasa lingkungan lainnya. Dalam peraturan ini juga berarti didalam taman nasional dapat digunakan sebagai jalur evakuasi akan tetapi diusahakan tidak merusak kondisi alami daerah tersebut.

Adanya pusat logistik di Kabupaten Bungo didasarkan oleh adanya keberadaan Kabupaten Kerinci yang berada pada wilayah struktur patahan besar sumatera yang disebut patahan semangko dan juga sebagai salah satu wilayah yang memiliki gunungapi aktif yang berada dalam gugus ring of fire. Adanya perencanaan pusat logistik diharapkan akan diikuti oleh adanya perencanaan pengelolaan bantuan logistik. Pengelolaan bantuan logistik dilakukan pada status keadaan 
darurat dimulai sejak status siaga darurat, tanggap darurat, dan transisi darurat ke pemulihan sesuai dengan penjelasan pasal 23 ayat (1) Peraturan Pemerintah Republik Indonesia Nomor 21 Tahun 2008 tentang Penyelenggaraan Penanggulangan Bencana. Undang-Undang Republik Indonesia Nomor 24 Tahun 2007 tentang Penanggulangan Bencana, khususnya dalam Pasal 6 dan Pasal 8 telah mengamanatkan bahwa Pemerintah dan Pemerintah Daerah bertanggung jawab dalam penyelenggaraan penanggulangan bencana, yang antara lain adalah memberikan perlindungan pada masyarakat dari dampak bencana, dan pemulihan kondisi dari dampak bencana, termasuk di dalamnya adalah bantuan logistik pada saat status keadaan darurat.

Berdasarkan data demografi hasil Sensus Penduduk tahun 2010 yang dilakukan oleh Badan Pusat Statistik (BPS), jumlah penduduk Kabupaten Bungo adalah sebanyak 302.558 orang yang terdiri dari 155.213 orang laki-laki dan 147.345 perempuan dengan sex ratio sebesar 105,34. Komposisi penduduk Kabupaten Bungo menunjukkan bahwa 31,01\% penduduk berusia muda (umur 0-14 tahun), 65,24\% berusia produktif (umur 15-64 tahun), dan hanya 3,75\% yang berumur 65 tahun lebih. Adanya potensi sumberdaya manusia yang ada merupakan aset yang sangat penting dalam pengelolaan dan keberlanjutan pusat logistik.

\section{METODOLOGI}

Teknis pengumpulan data dilakukan dengan melakukan survei instansional (data sekunder) dan survei lapangan (data primer). Survei data sekunder merupakan kegiatan pengumpulan data dan peta, uraian wilayah yang tersedia pada berbagai instansi terkait sebagai dasar perumusan masalah. Survei data primer diawali dengan interpretasi Peta Rencana Tata Ruang Wilayah (RTRW), Peta Rupabumi Indonesia, dan peta-peta tematik lain. Metode sampling yang dilakukan menggunakan metode purposive sampling. Purposive sampling dilakukan pada jalur jalan setapak yang sudah lama ditinggalkan. Selain itu adanya informasi aspek lingkungan fisik yang terkait dengan kebencanaan juga sangat diperlukan sebagai penunjang informasi yang memperkuat efektivitas pembukaan jalur evakuasi bencana. Di dalam merupakan kegiatan pengumpulan data berdasarkan pengecekan di lapangan menggunakan GPS pada lokasi alternative jalur evakuasi, penempatan pusat logistik dan pembuatan peta teknis.

Penilaian kelayakan Kabupaten rencana jalur evakuasi dan pusat logistik menggunakan metode SWOT. SWOT merupakan metode analisis perencanaan strategi (strategic planning) guna mengetahui adanya faktor lingkungan yang bersifat eksternal dan internal pada suatu usaha atau kegiatan yang akan dilaksanakan sehingga menghasilkan kesimpulan yang berguna untuk memberi masukan terhadap pengambilan keputusan strategi dan memberi masukan prioritas strategi terhadap apa yang sebaiknya dilakukan terlebih dahulu oleh pengambil keputusan. Metode SWOT 
merupakan analsis secara kualitatif yang mencakup dari $\mathrm{S}=$ Strengths, (Kekuatan), $\mathrm{W}=$ Weakness (Kelemahan), $\mathrm{O}=$ Opportunities (Peluang), $\mathrm{T}=$ Threats (Tantangan).

\section{HASIL DAN PEMBAHASAN}

\subsection{Potensi Bencana Provinsi Jambi}

Gempabumi yang terjadi di Sumatera merupakan gempabumi yang terdapat pada wilayah struktur patahan besar yang disebut patahan semangko. Patahan Sumatera pernah mengakibatkan gempabumi besar di pulau Sumatera seperti gempabumi Liwa tahun 1932, 1994, gempabumi Kerinci 1909, 1995 yang meninggalkan kerugian jiwa dan materi yang cukup besar. Rekaman gempabumi-gempabumi besar yang pernah terjadi dilaporkan berasal dari zona sumber subduksi di sepanjang barat daya pulau Sumatera. Gempabumi besar ini antara lain terjadi pada tahun 1833 $(\mathrm{M}=9.2), 1861$ (M=8.2), 1907 (M=7.6), Gempabumi Bengkulu tahun $2000(\mathrm{M}=7.8)$, dan terakhir ádalah gempabumi Aceh $(\mathrm{Mw}=8.9)$. Gempabumi-gempabumi banyak terjadi di sepanjang zona subduksi dan tingkat subduksi ini diperkirakan sekitar $60 \mathrm{~mm} /$ tahun (Prawirodirdjo, 1998)

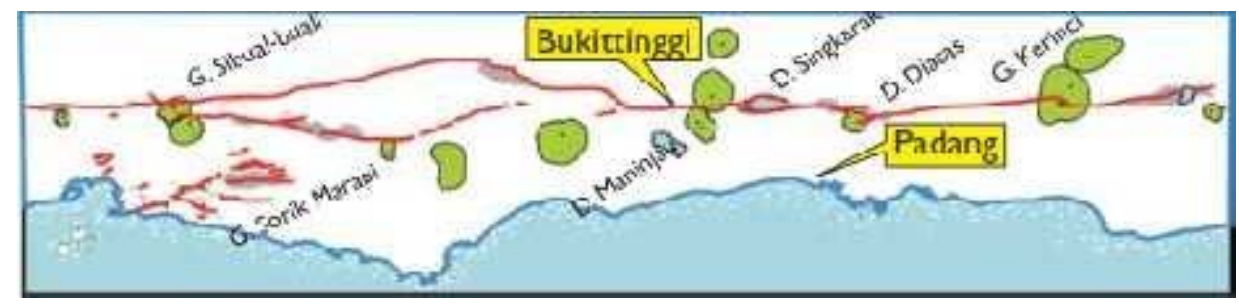

Gambar 1. Sebagian Patahan Semangko

Patahan tersebut menyimpan energi yang besar dan apabila suatu saat energi tersebut dilepaskan maka akan menimbulkan gempabumi. Apabila pelepasan energi tersebut secara tiba-tiba sekaligus inilah yang sangat berbahaya karena akan menimbulkan gempabumi yang dahsyat, namun kalau energi tersebut dilepas berangsur sedikit demi sedikit maka gempabumi yang ditimbulkan tidak terlalu berbahaya, bahkan kadang tidak dirasakan oleh manusia kecuali hanya tercatat oleh alat seismograf.

Daerah yang sangat berpotensi terhadap kejadian gempabumi di Provinsi Jambi adalah daerah Kabupaten Kerinci. Potensi gempabumi yang tinggi dapat dilihat dari adanya bidang sesar atau patahan yang cukup banyak dan kompleks. Potensi gempabumi cukup besar bukan hanya Kabupaten Kerinci tetapi Kabupaten Merangin, Kabupaten Batanghari, dan Kabupaten Tebo. Pada dasarnya Kabupaten Bungo juga memiliki patahan yang cukup banyak akan tetapi potensinya tidak seperti kabupaten yang lain.

Sejarah kegempabumian yang terdapat di Provinsi Jambi yang terakhir menimbulkan kepanikan terjadi pada tahun 2009. Saat itu kejadiannya terjadi Gempabumi bumi berskala 7.9 Skala Richter (SR) terjadi di Sumatra Barat dan Jambi berkekuatan 7 SR telah menimbulkan korban 
jiwa dan kerusakan pada bangunan-bangunan rumah warga, fasilitas dan sarana umum, sekolah, tempat usaha dan perkantoran pemerintah. Lebih dari 100 ribu rumah diperkirakan rusak berat dan ribuan bangunan umum hancur dan tidak dapat difungsikan kembali. Kejadian bencana ini mengganggu fungsi masyarakat, akses warga terhadap kebutuhan dasar. Banyak daerah yang terisolir akibat terjadinya gempabumi juga disertai oleh adanya tanah longsor. Kegiatan perekonomian setempat terganggu dan berpotensi menimbulkan dampak sosial ekonomi yang signifikan dalam jangka pendek dan menengah. Bencana yang terjadi belum dikaitkan dengan potensi bencana lain seperti tsunami dan gunungapi. Walaupun catatan sejarah belum menemukan kejadian tsunami dan kejadian Gunungapi Kerinci yang telah terjadi selama ini VEI (Vulcanic Eruption Index) berkisar angka 2 bukan berarti tidak perlu dilakukan rencana pengurangan risiko bencana. Seperti yang terjadi di Gunungapi Sinabung yang sekarang erupsi dengan VEI 4 padahal gunungapi tersebut sudah lama tidak aktif dan kalaupun aktif hanya berkisar VEI 2.

Hasil kajian bahaya gempa dan jalur evakuasi serta penetapan alternatif pusat logistik ini diperlukan untuk memberikan kriteria desain sebuah jalur evakuasi dari bahaya gempa dan gunungapi serta masukan dalam peraturan dan petunjuk jalur evakuasi dalam rangka pembangunan infrastruktur sebuah pusat logistik. Özdamar et al (2004) menyatakan perlunya perancangan integerasi kejadian bencana alam dengan penanganan rantai-pasokan komoditi sehingga dalam pengambilan keputusan tepat waktu-guna dan cepat. Pada umumnya kejadian bencana sarana dan prasarana utama seperti listrik, transportasi dan komunikasi tidak berjalan dengan normal bahkan bisa sama sekali tidak ada. Kabupaten Bungo dapat dijadikan tempat rantai-pasokan komoditi dan sarana pengiriman ke tempat terkena bencana gempa dan gunungapi yang terdapat di Kabupaten Kerinci bahkan dapat dijadikan sebagai pusat logistik alternative apabila terjadi bencana tsunami di barat Provinsi Jambi. Aliran kegiatan ini merupakan reliasasi fisik yang mengutamakan efektivitas bukan efisiensi dengan dukungan kebijakan. Selain itu kegiatan ini merupakan langkah yang baik dalam mewujudkan kerjasama yang baik antar daerah untuk mewujudkan kehidupan berkelanjutan berbasis bencana.

\subsection{Kondisi Alam Rencana Jalur Evakuasi}

Kondisi alam yang terdapat di jalur evakuasi ditinjau dari geologi, tanah, geomorfologi dan flora faunanya. Adanya peninjauan kondisi fisik lingkungan yang ada merupakan faktor utama yang menentukan kelayakan daerah tersebut untuk dijadikan jalur evakuasi. Berdasarkan kondisi stratigrafi pada Jalur evakuasi Kerinci - Bungo yang melintasi Kabupaten Bungo tepatnya Kecamatan Limbur Lubuk Mengkuang, melintasi dua Satuan yaitu Satuan Undifferentited Volcanic Rocks (Qyu) dan yaitu Satua Granit (Jgr). Satuan Undifferentited Volcanic Rocks (Qyu) terdiri dari Breksi Volkanik, Endapan Lahar, Breksi berfragmen Tuff dan Tuff. Satuan ini berasal dari kegiatan 
volkanik Gunung Kerinci dan Gunung Tujuh. Satuan ini terbentuk pada Zaman Kuarter dan melampar diatas Satuan Granit (Jgr). Satuan Batuan lainnya yang dilintasi oleh Jalur Evakuasi di wilayah Kabupaten Bungo yaitu Satuan Granit (Jgr) yang tersingkap secara spot-spot dan terletak di bawah Satuan Undifferentited Volcanic Rocks (Qyu) secara stratigrafi. Satuan ini terdiri dari Granit Biotit Hornblenda sampai Granodiorit, yang mempunyai ciri-ciri mempunyai bintik-bintik mineral mafik, keterdapatan apatit pada beberapa tempat, dan merupakan batuan intrusi dengan jenis Stock. Satuan ini menerobos pada Zaman Jura.

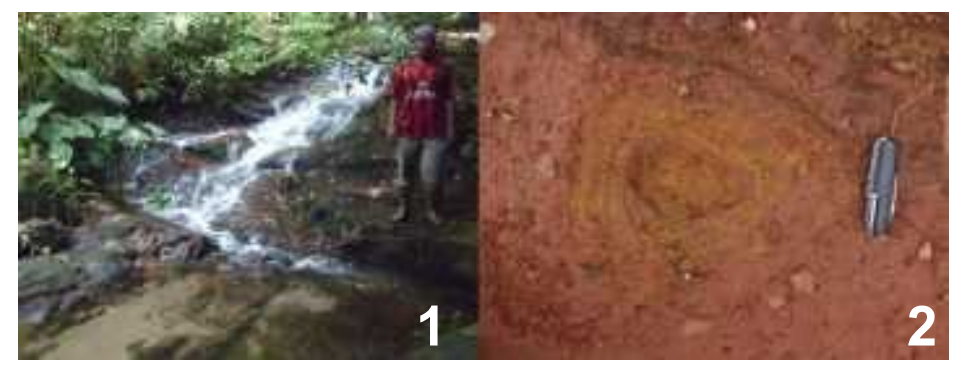

Gambar 2 (1) Singkapan Satuan Granit (Jgr) di lembah Sungai Batang Tebo, (2) Breksi Vulkanik pada Satuan

Undifferentiated Volcanic Rocks (Qyu) yang sudah lapuk dan mempunyai struktur Speroidal Weathering

Kondisi geomorfologi yang dilewati Jalur Evakuasi Kerinci Bungo melewati 2 Bentuk asal dan 4 Bentuk lahan. Bentuk asal berupa Vulkanik dan Struktural. Bentuk asal vulkanik mempunyai bentuk lahan dataran fluvial-vulkanik yang terdapat di sekitar Daerah pemukiman Renah Sungai Ipuh merupakan dataran dengan penyusun material vulkanik akibat dari proses fluviatil. Bentuk Asal Struktural memiliki bentuk lahan Punggungan Bergelombang Terjal, Dataran Bergelombang Rendah, dan Dataran Bergelombang Rendah-Tinggi. Bentuk Asal ini terbentuk karena proses endogen yaitu struktur geologi yang mempunyai peran membentuk bentuk lahan yang ada di daerah ini. Secara umum vegetasi alami di ekosistem sepanjang Jalur Evakuasi mencerminkan flora-flora yang khas dari kawasan Pulau Sumatera. Di kawasan Hutan Produksi dan Taman Nasional Kerinci Seblat menunjukkan tipe hutan lahan kering, dengan topografi perbukitan.

Analisis Kondisi flora fauna didapatkan dengan cara observasi-cepat di sepanjang Jalur Evakuasi Kerinci-Bungo. Informasi keberadaan jenis fauna bernilai konservasi di Areal Hutan Sepanjang Jalur Evakuasi juga diperoleh dari masyarakat sekitar hutan. Keberadaan fauna terestrial langka yang endemik Sumatera dapat dijadikan sebagai rujukan utama dalam penentuan Nilai Konservasi. Dalam hal ini keberadaan harimau sumatera (Panthera tigris sumatrae) dan gajah sumatera (Elephas maximus sumatrae). Kedua mamalia besar ini tergolong critically endangered, dan membutuhkan luasan tertentu sebagai daerah jelajah untuk kelangsungan hidupnya. Oleh karena itu penilaian terhadap keberadaan, kondisi-kondisi habitat untuk mempertahankan proses penting ekologi dan konektivitas ekologisnya dapat mengarahkan keputusan-keputusan dengan prinsip kehati-hatian. Pendekatan prinsip kehati-hatian ini akan dipertahankan agar Jalur Evakuasi 
tidak menimbulkan dampak negatif yang besar terhadap kelangsungan hidup fauna langka yang endemik Sumatera. Keberadaan dua fauna terestial bernilai konservasi tinggi dijumpai di Jalur Evakuasi yang melintasi: kawasan Hutan Produksi, sebagian Hutan Areal Penggunaan Lain di Bungo dan Hutan Taman Nasional Kerinci Seblat.

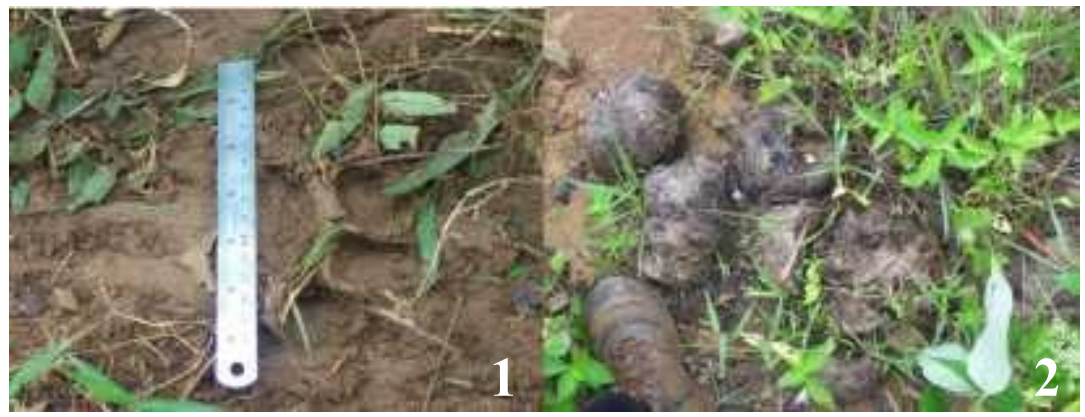

Gambar 3 (1) Jejak tapak kaki harimau sumatera di Jalur Evakuasi pada Hutan Area Penggunaan Lain. (2) Kotoran gajah sumatera di Jalur Evakuasi kawasan Hutan Produksi.

\subsection{Kelayakan Rencana Jalur Evakuasi dan Logistik Bencana Poros Kerinci - Bungo}

Penilaian kelayakan rencana jalur evakuasi dan logistik bencana poros Kerinci - Bungo dilakukan dengan analisis SWOT. Analisis ini merupakan tinjauan awal dalam pengambilan keputusan sebelum dilakukan tinjauan yang lebih lanjut. Dalam analisis SWOT juga telah dilakukan pertimbangan pada suatu permasalahan yang mungkin dapat ditimbulkan dan peluang pemecahannya.

\section{Kekuatan}

1. Merupakan daerah yang aman terhadap bencana gempabumi dan gunungapi

2. Dapat menghubungkan Kabupaten Kerinci dengan memotong daerah Taman Nasional dengan jarak terpendek daripada koridor yang lain yang sudah direncanakan di RTRW dengan morfologi terlandai dan rendah (kurang dari 1500 mdpal)

3. Spesies tumbuhan endemic mempunyai kerapatan rendah

4. Memiliki lokasi yang strategis baik di tingkat kabupaten maupun di tingkat regional Pulau Sumatra serta aksesbilitas dengan jalur lintas Sumatra sangat dekat

5. Adanya payung hukum yang jelas di dalam RTRW

Kelemahan

1. Jumlah penduduk masih sedikit sehingga sedikit terhambat dalam pengajuan anggaran

2. Diperlukan dana yang besar dalam pembuatan jalur evakuasi

3. Ketersediaan sarana dan prasarana kesehatan yang memadai di dekat jalur evakuasi belum ada

4. Tekstur tanah yang lempung berdebu menyebabkan konstruksi jalan harus dicor

5. Diperlukan pembangunan jembatan untuk menghubungkan Kabupaten Kerinci dan Kabupaten Bungo yang membutuhkan biaya cukup besar 
6. Belum adanya rencana kegiatan yang sama di Kabupaten Kerinci

7. Pembangunan pelabuhan dan fasilitas transportasi kurang didukung dengan anggaran yang memadai

Peluang

1. Dapat mempercepat proses evakuasi bencana

2. Pembukaan jalur evakuasi tidak berpotensi mengubah keseimbangan ekosistem

3. Kesehatan masyarakat sekitar akan meningkat seiring dengan adanya pembangunan fasilitas kesehatan dan bangunan logistik di dekat jalur evakuasi

4. Masyarakat sangat antusias program ini dapat terlaksana untuk mendukung pengembangan ekonomi.

5. Dibutuhkan peraturan yang ketat dalam mengatur perubahan penggunaan lahan di sekitar jalur evakuasi

6. Diperlukan semacam titik bantu atau jejaring pusat logistik dan dibuat semacam bangunan yang dapat dipergunakan untuk aktivitas masyarakat di dekat jalur evakuasi

7. Adanya pengetahuan tambahan terkait dengan keanekaragaman hayati yang terdapat di taman nasional

8. Dapat dijadikan alternatif pusat logistik di tingkat kabupaten hingga regional Pulau Sumatra

9. Perencanaan pembangunan bandara yang diperluas dengan landasan $2000 \mathrm{~m}$ sehingga pesawat besar dapat masuk sedangkan bandara bukan merupakan bandara dengan aktivitas yang ramai. Serta Adanya sungai dan dekat dengan jalur kereta api yang dapat dijadikan alternatif transportasi.

10. Merupakan daerah yang sedang mengalami pertumbuhan sehingga tidak sulit mencari lahan

11. pertumbuhan perekonomian daerah dan masyarakat akan meningkat yang berarti juga APBD Kabupaten Bungo akan semakin meningkat.

\section{Ancaman}

1. Semakin maraknya penebangan dan penambangan liar dan perubahan penggunaan lahan akan semakin intensif sehingga menimbulkan berkurangnya lahan yang digunakan sebagai tempat pertumbuhan biomassa

2. Adanya kesenjangan antara penduduk yang telah lama tinggal dengan pendatang.

3. Adanya pembangunan tidak diiringi dengan struktur bangunan yang kuat dan tidak memperhatikan faktor lingkungan maka meningkatkan potensi bencana tanah longsor

4. Potensi degradasi lahan semakin besar.

Berdasarkan analisis SWOT tersebut dan disertai oleh maka rencana jalur evakuasi poros Kerinci-Bungo dan logistik sangat layak. Walaupun layak tetapi tetap perlu adanya strategi dalam 
meminimalisir efek samping yang mungkin dapat terjadi. Strategi tersebut diantaranya : (1). Dalam proses pelaksanaan sebelumnya harus dilakukan penetapan peraturan dan strategi perlindungan lahan yang bersifat mengikat dan tegas terkait pelanggaran yang akan terjadi terutama perubahan penggunaan lahan. (2) Adanya perencanaan pembangunan wilayah di Kabupaten Bungo dan sekitarnya sebaiknya harus tetap berpihak pada kelestarian lingkungan untuk ketangguhan ekonomi dan sosial sehingga diharapkan dapat menjadi percontohan daerah lain dalam konteks pembangunan yang berkelanjutan. (3) Sebelum Kabupaten Bungo menetapkan jalur evakuasi terlebih dahulu perlu adanya penelitian yang lebih mendalam terkait jalur evakuasi yang terdapat di Kabupaten Kerinci yang menghubungkan jalur evakuasi yang telah direncanakan. (4) Agar pengawasan lingkungan terjaga dengan baik berbasis pemberdayaan masyarakat, maka pembukaan jalur evakuasi sebaiknya disertai dengan rencana daerah tersebut sebagai wisata alam, pendidikan dan penelitian keanekaragaman hayati sebagai langkah dalam melindungi taman nasional. Hal ini jelas akan mendatangkan pendapatan tambahan. (5) Selain itu, diperlukan pembuatan RPB (Rencana Penanggulangan Bencana) di Kabupaten Bungo sehingga kedudukan jalur evakuasi dan logistik untuk bencana gempabumi dan gunungapi memiliki status yang jelas dalam perencanaannya. Selain itu dengan adanya RPB yang sesuai dengan rencana srategis BNPB diharapkan dapat bantuan anggaran dari pusat sehingga tidak tergantung pada APBD.

\section{KESIMPULAN}

1. Berdasarkan karakter bencana dan aset yang berisiko terutama di Kabupaten Kerinci maka daerah yang layak dijadikan sebagai jalur evakuasi yang secara administrasi terletak pada Kecamatan Limbur Lubuk Mengkuang di Kabupaten Bungo dan terhubung ke Kecamatan Siluak Mukai di Kabupaten Kerinci, Provinsi Jambi.

2. Pembukaan lahan untuk jalur evakuasi tidak menyebabkan keanekaragaman hayati yang ada menjadi berkurang karena di dalam jalur evakuasi tidak ditemukan flora fauna yang langka yang dilindungi.

3. Kabupaten Bungo merupakan wilayah yang sangat cocok untuk dijadikan sebagai tempat pengembangan alternatif pusat logistik dengan mempertimbangakan posisi dan kondisi baik karakter bencana yang ada dan kondisi lingkungan eksisting yang ada.

4. Kebijakan pengembangan alternatif pusat logistik memiliki pengaruh yang besar dalam meningkatkan pembangunan daerah yang terdapat di Kabupaten Bungo walaupun memerlukan inventasi yang besar dalam pelaksanaannya. 


\section{Daftar Pustaka}

Natawidjaja, D.H., (2002), Ph.D Thesis, California Institute of Technology.

Özdamar, L., Ekinci, E., Küçükyzici, B., (2004), Emergency Logistiks Planning in Natural Disasters, Kluwer Academic Publishers, Manufatured in The Netherlands, Annals of Operation Research 129, 217-245.

Undang-Undang Nomor 24 Tahun 2007 tentang Penanggulangan Bencana.

Peraturan Pemerintah Nomor 21 Tahun 2008 tentang Penyelenggaraan Penanggulangan Bencana.

Peraturan Pemerintah Nomor 22 Tahun 2008 tentang Pendanaan dan Pengelolaan Bantuan Bencana.

Peraturan Menteri Kehutanan Nomor: P.56 /Menhut II/ 2006 Tentang Pedoman Zonasi Taman Nasional.

Peraturan Kepala BNPB Nomor 13 Tahun 2008 tentang manajemen logistik dan Peralatan Penanggulangan Bencana

Peraturan Kepala BNPB Nomor 18 Tahun 2009 tentang Standarisasi Logistik

Rencana Tata Ruang Wilayah Provinsi Jambi Tahun 2011-2030

SNI Pelayanan Darurat Kebencanaan 